\title{
AUDIT MONOMIALS AND POLYNOMIALS IN MEDIA
}

\section{Oksana Chaika,}

$\mathrm{PhD}$ (Linguistics), Associate Professor, Chair for Romance and Germanic

Languages and Translation

National University of Life and Environmental Sciences in Ukraine

E-mail: oxana.chaika@yahoo.es

The article presents an overview of English monomials and polynomials for audit and accounting in the media. The English language is a language for international business, law, economics, media and marketing. The media channels are over-flooded with the specific terminology. However, recently linguistic systems other than English have started absorbing the terms of English origin - implicitly or explicitly, and translating such by means of transcription or transliteration. The Ukrainian media, in which the professional domain of audit and accounting also finds it way, makes no exception. The international standards on audit and accounting, International Financial Reporting Standards and other globally accepted rules and regulations feed on mounts of English-borne terms in a language for audit and accounting, for instance Ukrainian for Audit and Accounting, German for Audit and Accounting, Chinese for Audit and Accounting, etc. The media is rich in such English-originating audit and accounting terms inasmuch Google or other engines may easily assist anyone with the search. Majority of relevant professional information is publicly available. Next, international and local business that carry out their activities in the field of audit and accounting use the specific terms and wording as basic content of their sites. They appeal to the target audience by creating a value to the customer. Finally, when launching a FaceBook page or creating an Instagram profile in addition to the professionally construed site, businesses do know that in order to win the e-marketing inbound methodology would do wonders. The media would definitely become 'Home, sweet home' to all professionals and business people provided they follow e-marketing strategy: Attract $\rightarrow$ Convert $\rightarrow$ Close $\rightarrow$ Delight. 
At the same time very few would pay attention to the structure of the terms in audit and accounting, and what is underlined in the paper is such terms act similarly to the algebraic expressions in mathematics. With proper collaboration of linguists and IT-people, media could benefit as well. Where content should be displayed in several languages, machine translation comes handy. In order to enable that, we propose a certain classification of the terms in audit and accounting, under which the terms are referred to as monomials and polynomials given the arithmetic nature.

Keywords: term, monomial, polynomial, audit and accounting, language for specific purpose, algebraic expression.

The novelty of the research and its scientific significance. The formulation of the problem and its relation to scientific and practical tasks.

The contemporary world is getting more and more digital with every day. Internet of things (IoT), artificial intelligence (AI) along with voice and face recognition industries are sky rocketing, thus, creating a different picture of our 'tomorrow'. The media would get overfilled with various content that may be characterized respectively of nature, target audience, marketing strategies etc. However, despite a wide range of applicable approaches to the vast canvases of information flow via media channels we may follow that the content is always strictly set in some terminological environment. It is obvious that we may speak here of relevant discourse analysis but for the purpose of our paper we suggest looking at the content associated with specific terms used in the area of audit and accounting. Given the fact that professional domain of usage attributes to different languages, it is also visible that majority of business terms, those in audit and accounting included without limitation, are generally of English origin.

\section{The analysis of resent researches and publications.}

According to Shair Ali Khan (2016), the main difference between a term and a word is the nature of reference. Term is characterized as monoreferential in a very specific concept at high degree relating to a specific area 
or field or discipline. It involves linguistic (lexical, syntactical and semantic) as well as concepts (generic, portative and casual) restrictions [17]. From this footing, we may see the difference between the term and the word. Following the idea of the paper audit and accounting would serve such specific area and/or field of discipline. Next, Carolina Popp (2001) mentions that terminography is the practical side of terminology as "it compiles, classifies and properly organizes nomenclatures which are terms sets of a particular field" [14]. To this end, we differentiate lexicography and terminography, in a broad sense of the word. Pearson (1998) highlights that the purpose of terms is fixing the relationship between term and concept to facilitate communication [13]. Further, Gelinas-Surprenant and Hussman (2015) emphasize on a specific field or discipline, e.g. engineering, medicine, law etc. and widen Lynne Bowker's definition relating to terminology as a discipline that deals with the collection, processing, description and presentation of terms which are lexical items belonging to a specialized subject field [8].

\section{The aim of the study.}

Based on the said and with all the due respect to the traditional concepts in applied linguistics and audit, the aim of the paper is:

(i) To facilitate bridging gaps in cross-disciplinary studies by connecting applied linguistics, IT and media worlds, on the one hand, and

(ii) To discuss the proposed classification of audit and accounting terms in the English language in very close correlation with the algebraic expression in mathematics, on the other.

Topicality of the paper rests on the two solid rock columns - terminology in linguistics and as its traditional application in media, and IT world with its algorithms and solution-able frameworks based on mathematics. Online data mining, big data and programming allow for more chances of success in relation to optimized solutions in language communication, accurate interpretations of short and long messages, and forecasts of precise 
recognition and representation of technical texts in professional domains.

\section{The presentation of the main research materials.}

The proposed idea would appeal to synchronising linguistic and mathematical patterns as exemplified with the English terms in audit and accounting. The findings of the research would aid design of bilingual and multilingual concordances that may improve quality of online machine translation.

To the extent within which mathematics sees an algebraic expression as:

- 'A symbol or a combination of symbols used in algebra, containing one or more numbers, variables, and arithmetic operations', and

- It is an amalgam of variables and constants of one or more terms (Chaika 2019),

The English term in audit and accounting may also be seen as an amalgam of variables and constants of one or more terms.

However, it is definitely confusing to analyse and describe terms of the term - by meaning elements of the term, provided we apply crossdisciplinarily approach to review the structure of the audit / accounting term through a lens of mathematics, or algebra, to be more exact.

That said we would propose to introduce another linguistic term for audit and accounting terms in English, thus, adopting the Maths terminology. Next, algebraic expressions may include symbols or operations like 'add', 'subtract', 'multiply', and 'divide'. Similarly, the English terms in audit and accounting may be set irreversibly by forming a strictly laid-out terminological setting. Thus, the matching principle attributable to the analysed patterns has provided the newly-emerging classification:

(1) Monomials in English for Audit and Accounting would act similarly to an algebraic expression that includes only one non-zero term.

For example, $\boldsymbol{p}$ is a monomial in one variable $\boldsymbol{p}$ in the algebraic expression as compared to audit in one variable audit in the English audit and accounting 
terminology. Further, $2 \boldsymbol{a} \boldsymbol{b}$ is a monomial in two variables $\boldsymbol{a}$ and $\boldsymbol{b}$ in the algebraic expression. In the English audit and accounting online terminological text setting, we may encounter financial statements (statements as a common noun expressed in plural and financial as an adjective, a noun-modifying attribute in pre-position) used twice, for instance, in the principal clause and the subordinate one when repeated given the technicality of linguistic restrictions in the professional domain of usage.

(2) Polynomials in English for Audit and Accounting would act similarly to an algebraic expression that has one, two or more terms. To illustrate the explanation, let us look at the algebraic expression of $2 \boldsymbol{a}+\boldsymbol{b}$. It is a polynomial of two terms in two variables a and $\boldsymbol{b}$ in algebra. In English for Audit and Accounting, let us consider the following example:

- Assurance skills AND techniques 'those planning, evidence gathering, evidence evaluation, communication and reporting skills and techniques demonstrated by an assurance practitioner that are distinct from expertise in the underlying subject matter of any particular assurance engagement or its measurement or evaluation' [IAAS (I), p. 20] — a polynomial in three variables (1) assurance, (2) skills, (3) techniques (Chaika 2019).

Furthermore, polynomials may be subdivided into binomials and trinomials in connection with the number of non-zero terms in both algebra and linguistics, terminology, in particular:

(a) Binomials in algebra refer to an algebraic expression that has two non-zero terms, e.g. $\boldsymbol{a}^{\mathbf{2}}+\mathbf{2} \boldsymbol{b}$, which is a binomial in two variables $\boldsymbol{a}$ and $\boldsymbol{b}$. In English for Audit and Accounting, due and reasonable care 'care which reasonably prudent man would exercise under circumstances' — a binomial in three variables (1) due, (2) reasonable, and (3) care. 
(b) Trinomials in both algebra and the English audit and accounting terminology refer an [algebraic] expression that has three non-zero terms, e.g. $\boldsymbol{x}+\boldsymbol{y}+\boldsymbol{z}$ is a trinomial in three variables $\boldsymbol{x}, \boldsymbol{y}$ and $\boldsymbol{z}$. In English for Audit and Accounting, Handbook of International Quality Control (1), Auditing (2), Review (3), Other Assurance (4), and Related Services (5) Pronouncements is an absolute polynomial rather than a trinomial, by aggregating five variables as opposed to three that characterize a trinomial.

With some insights into the above classification of monomials and polynomials in English for Audit and Accounting, we would specify that a monomial terminological set expression in English for Audit and Accounting, as well as may be referred to as a monomial or a monomial term, means only one term, which can be extended with a modifier/modifiers or unextended. Next, a polynomial terminological set expression, or a polynomial, or a polynomial term in English for Audit and Accounting means a sum of two or more terms, which can be extended with a modifier / modifiers or remain unextended, respectively. Linguistically speaking, the operation of addition (or subtraction) links to the use of a relevant conjunction. In majority of cases, the roles associate with the two of them - and and or [4, 103], according to the classification by Oksana Chaika introduced in Monomial Variables in English Audit Terminology published in the International Journal of Philology (2019).

\section{Conclusions and prospects of the further research.}

To conclude, it is relevant to note that the systematic relations appear similar in an algebraic expression in mathematics and a terminological set expression in the English audit and accounting terminology. The relations and/or difference between monomial variables may determine the key concept of the term itself in both algebra and English audit and accounting set expression. The paper presents a substitute for the traditionally accepted term of the term in linguistics with the introduced terms of a monomial 
and polynomial respective of the term environment in connection with the cross-disciplinary study. The further study of the structure associated with monomials and polynomials in English for Audit and Accounting may find richly stored materials in online sources, experimenting with the classification for text mining and attracting IT experts as well. Today, the role of media is growing critical. Media may be used not only for newsfeed online, business promotion via sites and internet, online sales funnels and so on, but also to help integrate linguistic findings into the software solutions.

\section{Література:}

1. Aronoff M., Rees-Miller J. The Handbook of Linguistics. Hoboken. NJ : John Wiley \& Sons, 2017.

2. Cabré M. T. Terminología y lingüística: la teoría de las puertas abiertas. Estudios de Lingüística del Español (ELiEs). Red Iris. España : Universidad Autónoma de Barcelona, 2002.

3. Chaika O. Language for Specific Purposes : Ukrainian Legal Terms of Obligation, 2018. pp. 52-59.

4. Chaika O. Monomial Variables in English Audit Terminology. International journal of philology. 2019. Vol. 10. №1. pp. 100-108.

5. Chaika O. Ukrainian for Law and Portuguese for Law as 'Understudied' Languages for Specific Purposes. Філологічний часопис. 2018. Вип. 1 (11). С. 118-127.

6. Chaika O., Bambura A. Structure of English Business Monomials. Linguistic Bulletin. 2019. №27.

7. Cruse A. Meaning and Language : An introduction to Semantics and Pragmatics. Oxford Textbooks in Linguistics. 2004. Chapter 1.

8. Gelinas-Surprenant G., Hussman G. Canadian Terminology. Standardizing Terminology for Better Communication. Practice. Handbook of Terminology. 2015. Vol. 1. pp. 304-323. URL: https://benjamins.com/ online/hot/link/articles/ter5 (дата звернення: 01.12.2019). 
9. Hutchins J. Retrospect and prospect in computer-based translation. Proceedings of MT. 1999. Summit VII. pp. 30-44.

10. Jurafsky D., Martin J. H. Speech and language processing : An introduction to natural language processing, computational linguistics, and speech recognition. Upper Saddle River. NJ : Pearson Prentice Hall, 2009.

11. Kockaert H. J., Steurs F. Handbook of Terminology. Amsterdam, Philadelphia, John Benjamins. 2014. Vol. 1.

12. Лучик А. А. Динаміка мовної норми і проблеми кодифікації. Магістеріум. Мовознавчі студіi. 2016. Вип. 62. С. 51-55.

13. Pearson J. Term in Context. John Benjamin Publishing. 1998.

14. Popp C. Nomenclatures and computer-aided terminography. In F. Mayer (Ed), Language for special purpose: perspectives for the new millennium. Narr, Tubingen, 2001. pp. 195-201.

15. Salvi G., Montesano L., Bernardino A., Santos-Victor J. Language bootstrapping: learning word meanings from perception-action association. IEEE transactions on systems, man, and cybernetics. Cybernetics : a publication of the IEEE Systems, Man, and Cybernetics Society. 2012. Part B. Vol. 42 (3). pp. 660-671.

16. Santamaría Pérez I. La terminología: definicíon, funciones y aplicaciones. Biblioteca de recursos electrónicos de humanidades. E-exceLence para red de comunicaciones Internet. 2006.

17. Shair Ali Khan. The Distinction between Term and Word : A Translator and Interpreter Problem and the Role of Teaching Terminology. Procedia : Social and Behavioral Sciences. International Conference on Teaching and Learning English as an Additional Language, GlobELT. 14-17 April 2016. Antalya, Turkey. 2016.

18. Soare R. I. Computability Theory and Applications : The Art of Classical Computability. 2011.

19. Sonneveld H, Loenning, K. Introducing terminology. Terminology, 1994. pp. 1-6. 
20. Wüster E. Einführung in die allgemeine Terminologielehre und terminologische Lexikographie. Springer-Verlag. 1979. Teil 1-2.

УДК $81 ‘ 32: 811.111: 81$ ‘276.6 $\quad$ DOI: https://doi.org/10.18524/2308-3255.2019.25.195597

\section{Аудит-мономиалы и полимиалы в медиапространстве}

\section{Оксана Чайка,}

доктор философии (лингвистика), доцент кафедры

романо-германских языков и перевода

Национальный университет биоресурсов и природопользования Украины e-mail: oxana.chaika@yahoo.es

Статья посвящена изучению английских терминов (мономиалов и полимиалов) в области учета и аудита в медиапространстве. Украинское медиапространство, когда речь идет о профессиональном поле использования терминов аудита и учета, отмечается логикой и последовательностью использования значительного количества терминов английского происхождения. Украинские соответствия часто характеризуются в переводе применением либо транслитерации, либо транскрибирования. Однако в последнее время украинский язык переполняется вновь рожденными терминами - заимствованиями из английского языка, причем языковые эквиваленты в украинском игнорируются. Засилье английских терминов отслеживается независимо от медиафокуса, начиная с поиска в Google и заканчивая изложением контента на бизнес-сайтах аудиторских компаний, компаний, занимающихся так называемым аутстаффингом и аутсорсингом (от англ. outstaffing и outsourcing). При запуске бизнес-страницы в Фейсбук или Инстаграм значительному количеству современных маркетологов представляется правильным и конкурентоспособным подходом наполнять и продвигать медиаканалы с помощью английских терминов, полностью пренебрегая использования их украинских соответствий. Стратегии е-маркетинга (цифрового маркетинга) Attract $\rightarrow$ Convert $\rightarrow$ Close $\rightarrow$ Delight сосредоточены скорее на структуре и содержании собственно контента, нежели на структуре тех терминов, которые направлены на изложение экспертного мнения и описания бизнеса как одного из 
методов привлечения и удержания целевой аудитории. Продуктом статьи является предложенная классификация английских терминов (мономиалов) в сфере учета и аудита, что в будущем может помочь созданию электронных конкордансов и работе с большими массивами данных в медиапространстве, использовании таких в целях искусственного интеллекта (AI) и Интернета вещей (IoT).

Ключевые слова: термин, мономиал, полимиал, аудит и учет, алгебраическое выражение.

УДК $81 ‘ 32: 811.111: 81^{‘} 276.6 \quad$ DOI: https://doi.org/10.18524/2308-3255.2019.25.195597

\section{Аудит-мономіали та поліміали в медіапросторі}

\section{Оксана Чайка,}

доктор філософії (лінгвістика), доцент кафедри

романо-германських мов і перекладу

Національний університет біоресурсів і природокористування України e-mail: oxana.chaika@yahoo.es

Статтю присвячено вивченню англійських термінів (мономіалів i поліміалів) у сфері обліку й аудиту в медіапросторі. Український медіапростір, коли мова йде про професійне поле використання термінів аудиту й обліку, відзначається логікою й послідовністю використання значної кількості термінів англійського походження. Українські відповідники часто характеризуються в перекладі застосуванням або транслітерації, або транскрибування. Проте останнім часом українська мова переповнюється новоствореними термінами - запозиченнями з англійської мови, причому мовні еквіваленти в українській ігноруються. Засилля англійських термінів відстежується незалежно від медіафокусу, починаючи з пошуку в Google та закінчуючи викладенням контенту на бізнес-сайтах аудиторських компаній, компаній, що займаються так званим аутстаффінгом і аутсорсингом (від англ. outstaffing та outsourcing). При запуску бізнес-сторінки у Фейсбук чи Інстаграм значній кількості сучасних маркетологів видається правильним і конкурентноздатним підходом наповнювати та просувати медіаканали за допомогою англійських 
термінів, повністю зневажаючи використання їхніх українських відповідників. Стратегії е-маркетингу Attract $\rightarrow$ Convert $\rightarrow$ Close $\rightarrow$ Delight зосереджені радше на структурі й змісті власне контенту, ніж на структурі тих термінів, що спрямовані на викладення експертної думки й опису бізнесу як одного з методів залучення й утримання цільової аудиторії. Продуктом статті є запропонована класифікація англійських термінів (мономіалів) у сфері обліку й аудиту, що в майбутньому може посприяти створенню електронних конкордансів та роботі 3 великими масивами даних у медіапросторі, використанні таких у цілях штучного інтелекту (АI) та інтернету речей (ІоТ).

Ключові слова: термін, мономіал, поліміал, облік й аудит, алгебраїчний вираз.

\section{References:}

1. Aronoff, M., Rees-Miller, J. (2017). The Handbook of Linguistics. Hoboken. [In English].

2. Cabré, M. T. (2002). Terminología y lingüística: la teoría de las puertas abiertas. Estudios de Lingüística del Español (ELiEs). Red Iris. España. [In Spanish].

3. Chaika, O. Language for Specific Purposes : Ukrainian Legal Terms of Obligation, pp. 52-59 [In English].

4. Chaika, O. (2019) Monomial Variables in English Audit Terminology. International journal of philology. Vol. 10. № 1. pp. 100-108 [In English].

5. Chaika, O. (2018). Ukrainian for Law and Portuguese for Law as 'Understudied' Languages for Specific Purposes. Philological journal. Vol. 1 (11). pp. 118-127 [In English].

6. Chaika, O., Bambura, A. (2019) Structure of English Business Monomials. Linguistic Bulletin. Vol. 27 [In English].

7. Cruse, A. (2004). Meaning and Language : An introduction to Semantics and Pragmatics. Oxford Textbooks in Linguistics. Chapter 1. [In English].

8. Gelinas-Surprenant, G. Hussman, G. (2015). Canadian Terminology. Standardizing Terminology for Better Communication. Practice. Handbook of Terminology. Vol. 1. pp. 304-323. URL: https://benjamins.com/online/hot/link/ articles/ter5 (accessed: 01.12.2019) [In English].

9. Hutchins, J. (1999). Retrospect and prospect in computer-based translation. 
Proceedings of MT. Vol. VII. pp. 30-44 [In English].

10. Jurafsky, D., Martin, J. H. (2009). Speech and language processing: An introduction to natural language processing, computational linguistics, and speech recognition. Upper Saddle River. [In English].

11. Kockaert, H. J., Steurs, F. (2014). Handbook of Terminology. Amsterdam, Philadelphia. Vol. 1. [In English].

12. Luchyk, A. (2016). Dynamika movnoyi normy i problemy kodyfikatsiyi [Dynamics of language norm and codification problem]. Magisterium. Vol. 62. pp. 51-55 [In Ukrainian].

13. Pearson, J. (1998). Term in Context. John Benjamin Publishing [In English].

14. Popp, C. (2001). Nomenclatures and computer-aided terminography. Language for special purpose: perspectives for the new millennium. Narr, Tubingen. pp. 195-201. [In English].

15. Salvi, G., Montesano, L., Bernardino, A., Santos-Victor, J. (2012). Language bootstrapping: learning word meanings from perception-action association. IEEE transactions on systems, man, and cybernetics. Cybernetics : a publication of the IEEE Systems, Man, and Cybernetics Society. Part B. Vol. 42(3). pp. 660-671 [In English].

16. Santamaría Pérez, I. (2006). La terminología: definicíon, funciones y aplicaciones. Biblioteca de recursos electrónicos de humanidades. E-exceLence para red de comunicaciones Internet [In Spanish].

17. Shair, Ali Khan (2016) The Distinction between Term and Word: A Translator and Interpreter Problem and the Role of Teaching Terminology. Procedia : Social and Behavioral Sciences. International Conference on Teaching and Learning English as an Additional Language, GlobELT. 14-17 April 2016. Turkey. [In English].

18. Soare, R. I. (2011). Computability Theory and Applications : The Art of Classical Computability [In English].

19. Sonneveld, H, Loenning, K. (1994). Introducing terminology. Terminology. pp. 1-6. [In English].

20. Wüster, E. (1979). Einführung in die allgemeine Terminologielehre und terminologische Lexikographie. Springer-Verlag. Vol. 1-2. [In German]. 